\title{
Anti-Müllerian hormone receptor type 2 is expressed in gonadotrophs of postpubertal heifers to control gonadotrophin secretion
}

\author{
Onalenna Kereilwe ${ }^{\mathrm{A}}$, Kiran Pandey ${ }^{\mathrm{A}}$, Vitaliano Borromeo ${ }^{\mathrm{B}}$ \\ and Hiroya Kadokawa ${ }^{\mathrm{A}, \mathrm{C}}$ \\ A Faculty of Veterinary Medicine, Yamaguchi University, Yamaguchi-shi, \\ Yamaguchi-ken 1677-1, Japan. \\ ${ }^{B}$ Dipartimento di Medicina Veterinaria, Università degli Studi di Milano, 26900, Italy. \\ ${ }^{\mathrm{C}}$ Corresponding author. Email: hiroya@yamaguchi-u.ac.jp
}

\begin{abstract}
Preantral and small antral follicles may secret anti-Müllerian hormone (AMH) to control gonadotrophin secretion from ruminant gonadotrophs. The present study investigated whether the main receptor for AMH, AMH receptor type 2 (AMHR2), is expressed in gonadotrophs of postpubertal heifers to control gonadotrophin secretion. Expression of AMHR 2 mRNA was detected in anterior pituitaries (APs) of postpubertal heifers using reverse transcription-polymerase chain reaction. An anti-AMHR2 chicken antibody was developed against the extracellular region near the $\mathrm{N}$-terminus of bovine AMHR2. Western blotting using this antibody detected the expression of AMHR2 protein in APs. Immunofluorescence microscopy using the same antibody visualised colocalisation of AMHR2 with gonadotrophin-releasing hormone $(\mathrm{GnRH})$ receptor on the plasma membrane of gonadotrophs. AP cells were cultured for 3.5 days and then treated with increasing concentrations $\left(0,1,10,100\right.$, or $\left.1000 \mathrm{pg} \mathrm{mL}^{-1}\right)$ of AMH. AMH $\left(10-1000 \mathrm{pg} \mathrm{mL}^{-1}\right)$ stimulated $(P<0.05)$ basal FSH secretion. In addition, AMH $\left(100-1000 \mathrm{pg} \mathrm{mL}^{-1}\right)$ weakly stimulated $(P<0.05)$ basal LH secretion. AMH (100-1000 $\left.\mathrm{pg} \mathrm{mL}^{-1}\right)$ inhibited GnRH-induced FSH secretion, but not GnRH-induced LH secretion, in AP cells. In conclusion, AMHR2 is expressed in gonadotrophs of postpubertal heifers to control gonadotrophin secretion.
\end{abstract}

Additional keywords: AMHR2, gonadotrophin-releasing hormone (GnRH) receptor, Müllerian-inhibiting substance, ruminant.

Received 20 September 2017, accepted 14 February 2018, published online 14 March 2018

\section{Introduction}

Gonadotrophs in the anterior pituitary (AP) secrete gonadotrophins, LH and FSH to regulate follicle growth, ovulation and corpus luteum (CL) formation in ovaries of vertebrates. Acting as a feedback mechanism, antral follicles and CL secrete steroids and inhibin to control gonadotrophin secretion from the AP (Martin et al. 1991). This pituitary-ovary-axis is one of the most important fundamental mechanisms for reproduction. However, it is not clear whether hormones secreted from preantral and small antral follicles control gonadotrophin secretion from the AP. We question whether preantral and small antral follicles are a silent majority in ovaries.

Anti-Müllerian hormone (AMH) is a dimeric glycoprotein in the transforming growth factor TGF $\beta$ (TGF $\beta$ ) family and, in humans and animals, $\mathrm{AMH}$ is primarily produced by granulosa cells of preantral and small antral follicles (Bhide and Homburg 2016). AMH regulates follicular development during the gonadotrophin-responsive phase (Hernandez-Medrano et al. 2012) and inhibits follicular atresia (Seifer and Merhi 2014). Blood AMH concentrations are indicative of ovarian aging in women (Dewailly et al. 2014; Bhide and Homburg 2016). Plasma AMH concentrations are positively correlated with pregnancy rates in dairy cows (Ribeiro et al. 2014). Further, circulating AMH concentrations can predict the number of high-quality embryos produced by a donor goat or cow (Ireland et al. 2008; Monniaux et al. 2011). These data suggest the importance of AMH for proper reproductive function in ruminants after puberty.

Although the primary role of AMH is at the level of the ovary in female animals, AMH secreted from preantral and small antral follicles into circulating blood may have actions in other organs. Indeed, the APs of adult rats express mRNA for the main receptor of $\mathrm{AMH}, \mathrm{AMH}$ receptor type 2 (AMHR2; Bédécarrats et al. 2003). AMH activates $L H \beta$ and $F S H \beta$ gene expression in L $\beta$ T2 cells, a murine gonadotroph-derived cell line (Bédécarrats et al. 2003). Garrel et al. (2016) recently reported that $\mathrm{AMH}$ stimulates FSH secretion in rats in vivo; however, such stimulation is restricted to prepubertal female rats. There are still no data on the regulatory role of $\mathrm{AMH}$ 
Table 1. Details of the three primers used for polymerase chain reaction to detect anti-Müllerian hormone receptor type 2 (AMHR2) mRNA in bovine anterior pituitaries

\begin{tabular}{llccc}
\hline Primer pair & Sequence $\left(5^{\prime}-3^{\prime}\right)$ & $\begin{array}{c}\text { Position } \\
\text { Nucleotide }\end{array}$ & Exon & \\
\hline 1 st & Forward GATTTGCGACCTGACAGCAG & $1273-1292$ & $9-10$ & 340 \\
& Reverse CGGGAGGAGTGGAGAAATGG & $1593-1612$ & 11 & \\
\multirow{2}{*}{ nd } & Forward AGATTTGCGACCTGACAGCAG & $1272-1292$ & $9-10$ & 320 \\
& Reverse CTTCCAGGCAGCAAAGTGAG & $1572-1591$ & 11 & \multirow{2}{*}{3 rd } \\
& Forward GTGCTTCTCCCAGGTCATACG & $606-626$ & $5-6$ & 277 \\
& Reverse GGTGTGCTGGGTCAAGTAGT & $863-882$ & 7 & \\
\hline
\end{tabular}

on gonadotrophin secretion from gonadotrophs in ruminant species.

Gonadotrophs are controlled by gonadotrophin-releasing hormone $(\mathrm{GnRH})$ via the $\mathrm{GnRH}$ receptor (GnRHR), present in lipid rafts in the plasma membrane of gonadotrophs (Navratil et al. 2009; Kadokawa et al. 2014; Wehmeyer et al. 2014). The lipid rafts are distinct, relatively insoluble regions that have lower density and are less fluid than the surrounding membrane (Simons and Tooter 2000; Head et al. 2014), and they facilitate signalling by allowing colocalisation of membrane receptors and their downstream signalling components (Simons and Tooter 2000; Head et al. 2014). We recently discovered that two orphan receptors, namely GPR61 and GPR153, are colocalised with GnRHR in gonadotroph plasma membrane lipid rafts (Pandey et al. 2017, 2018). Therefore, gonadotroph lipid rafts containing GnRHR may contain AMHR2. In the present study, we tested the hypothesis that AMHR2 is expressed in the gonadotrophs of postpubertal heifers to control gonadotrophin secretion.

\section{Materials and methods}

\section{$A P$ and ovary sample collection}

AP tissue was obtained from postpubertal (26 months of age) Japanese Black heifers at a local abattoir, using a previously described method (Kadokawa et al. 2014). The heifers were in the middle luteal phase (i.e. 8-12 days after ovulation), as determined by macroscopic examination of the ovaries and uterus (Miyamoto et al. 2000); the AP show the highest LH and GnRHR concentrations in this phase (Nett et al. 1987).

Granulosa cells in small antral follicles express $A M H R 2$ mRNA (Poole et al. 2016). Therefore, we also collected ovary tissue samples from the same heifers to use as positive controls for AMHR2 in western blotting and immunohistochemical assays.

The AP and ovary samples for RNA or protein $(n=3)$ extraction were immediately frozen in liquid nitrogen and stored at $-80^{\circ} \mathrm{C}$. The AP and ovary samples for immunohistochemistry $(n=5)$ were fixed in $4 \%$ paraformaldehyde at $4^{\circ} \mathrm{C}$ for $16 \mathrm{~h}$. The AP samples meant for cell culture followed by immunocytochemical analysis $(n=5)$ and those that were to be used for cell culture to evaluate the effect of AMH on $\mathrm{LH}$ and FSH secretion $(n=8)$ were stored in ice-cold $25 \mathrm{mM}$ HEPES buffer $(\mathrm{pH} 7.2)$ containing $10 \mathrm{mM}$ glucose and transported on ice to the laboratory.
Reverse transcription-polymerase chain reaction, sequencing of amplified products and homology search in gene databases

Total RNA was extracted from the AP samples $(n=3)$ using RNAiso Plus (Takara Bio) according to the manufacturer's instructions. The extracted RNA samples were treated with ribonuclease-free deoxyribonuclease (Toyobo) to eliminate possible genomic DNA contamination. Using a NanoDrop ND-1000 spectrophotometer (NanoDrop Technologies), the concentration and purity of each RNA sample were evaluated to ensure that the ratio of absorbance at $260 / 280 \mathrm{~nm}\left(\mathrm{~A}_{260} / \mathrm{A}_{280}\right)$ was in the acceptable range of 1.8-2.1. The mRNA quality of all samples was verified by electrophoresis of total RNA followed by staining with ethidium bromide, and the $28 S: 18 S$ ratios were $2: 1$. The cDNA was synthesised from $0.5 \mu \mathrm{g}$ total RNA per AP using ReverTra Ace qPCR RT Master Mix (Toyobo) according to the manufacturer's instructions.

In order to determine the expression of $A M H R 2$ mRNA in the $\mathrm{AP}$, polymerase chain reaction (PCR) was conducted using one of three pairs of primers designed by Primer 3 based on the reference sequence of bovine AMHR2 (National Center for Biotechnology Information (NCBI) reference NM_001205328.1), as one of PCR primers must span an exon-exon junction. The primer pairs are listed in Table 1; the expected sizes of the PCR products of AMHR2 were 340,320 and 277 bp. Using a Veriti 96-Well Thermal Cycler (Thermo Scientific), PCRs were performed using $20 \mathrm{ng}$ cDNA and polymerase (Tks Gflex DNA Polymerase; Takara Bio) under the following thermocycles: $94^{\circ} \mathrm{C}$ for $1 \mathrm{~min}$ for predenaturing, followed by 35 cycles of $98^{\circ} \mathrm{C}$ for $10 \mathrm{~s}, 60^{\circ} \mathrm{C}$ for $15 \mathrm{~s}$ and $68^{\circ} \mathrm{C}$ for $30 \mathrm{~s}$. PCR products were separated on $1.5 \%$ agarose gels by electrophoresis with a molecular marker (Gene Ladder 100 (0.1-2 kbp); Nippon Gene), stained with fluorescent stain (Gelstar; Lonza) and observed using a charge-coupled device (CCD) imaging system (GelDoc; Bio-Rad). The PCR products were purified using a NucleoSpin Extract II kit (Takara Bio) and then sequenced with a sequencer (ABI3130; Thermo Fisher Scientific) using one of the PCR primers and the Dye Terminator v3.1 Cycle Sequencing Kit (Thermo Fisher Scientific). The sequences obtained were used as query terms with which to search for homology sequences in the DDBJ/ GenBank/EBI data bank using the basic nucleotide local alignment search tool (BLAST) optimised for highly similar sequences (available on the NCBI website). 


\section{Development anti-AMHR2 chicken antibody}

Previously, using the SOSUI v.1.11 algorithm (Hirokawa et al. 1998; http://harrier.nagahama-i-bio.ac.jp/sosui/, accessed 10 March 2016, we determined that bovine AMHR2 protein (543 amino acids; Accession no. NP_001192257.1 in NCBI reference bovine sequences) contains one hydrophobic transmembrane domains (amino acids 146-168) linked by hydrophilic extracellular and intracellular regions. This structure is the same as the reported structure of mouse AMHR2 (Sakalar et al. 2015).

Genetyx ver. 11 (Gentyx) was used to predict antigenic determinants based on an algorithm derived by Hopp and Woods (1981). For antibody production, a peptide corresponding to amino acids 31-45 (GVRGSTQNLGKLLDA), an extracellular region that is located near the N-terminus of AMHR2, was used for three reasons. First, this peptide has no homology to the corresponding region of chicken AMHR2 (XP_015145444.1). Second, the peptide sequences are in a region downstream of the signal peptide of bovine AMHR2 (amino acids 1-17). Third, we confirmed that no other protein encoded in the bovine genome exhibited homology with the peptide sequences of the AMHR2 by comparison with sequences retrieved from the DDBJ/GenBankTM/EBI data bank using BLAST.

A commercial service (Scrum) was used for the synthesis of the antigen peptide (C-GVRGSTQNLGKLLDA), conjugation with keyhole limpet haemocyanin (KLH), immunisation and antibody purification. Briefly, the peptide was synthesised and the purity $(>99.0 \%)$ verified using HPLC followed by mass spectrometry. Then, KLH was conjugated to the sulfhydryl group of the cysteine to produce an immunogen that was then emulsified with Complete Freund's adjuvant and injected into chickens five times at 14-day intervals. Blood was collected 7 days after the final immunisation and the antibody was purified by affinity column chromatography (PD10; GE Healthcare) containing an antigen-conjugated gel prepared with the SulfoLink Immobilisation Kit (Thermo Scientific).

\section{Other antibodies used in the present study}

We previously developed a guinea pig polyclonal antibody that recognises the $\mathrm{N}$-terminal extracellular domain (corresponding to amino acids 1-29; MANSDSPEQNENHCSAINSSIPLTPGSLP) of GnRHR (anti-GnRHR). The specificity of the anti-GnRHR antibody was verified by western blotting, and pretreatment with anti-GnRHR antibody inhibited GnRH-induced LH secretion from cultured bovine gonadotrophs (Kadokawa et al. 2014). In addition, we previously used the anti-GnRHR antibody for immunofluorescence detection of GnRHR in the plasma membrane of bovine gonadotrophs (Kadokawa et al. 2014; Pandey et al. 2016). We observed a strong and localised GnRHR-positive staining signal as an aggregation on the plasma membrane of gonadotrophs (Kadokawa et al. 2014). In the present study, we used the anti-GnRHR antibody and a mouse monoclonal anti-LH $\beta$ antibody (Clone 518-B7; Matteri et al. 1987) for immunohistochemical analysis of AP tissue and cultured AP cells. This anti-LH- $\beta$ antibody does not crossreact with other pituitary hormones (Iqbal et al. 2009). We also used a mouse monoclonal anti-FSH $\beta$ subunit antibody (Clone $\mathrm{A} 3 \mathrm{C} 12$ ) that does not cross-react with other pituitary hormones
(Borromeo et al. 2004) for immunohistochemical analysis of AP tissue.

\section{Western blotting for AMHR2}

Briefly, protein was extracted from AP $(n=3)$ or ovary $(n=3$; positive control) samples and western blotting was performed as previously described (Kadokawa et al. 2014). The extracted protein $(33.4 \mu \mathrm{g}$ total protein in $37.5 \mu \mathrm{L})$ was mixed in $12.5 \mu \mathrm{L}$ of $4 \times$ Laemmli sample buffer (Bio-Rad) containing $10 \%(\mathrm{v} / \mathrm{v})$ $\beta$-mercaptoethanol, then boiled for $3 \mathrm{~min}$ at $100^{\circ} \mathrm{C}$. Boiled protein samples were quickly cooled in ice, then 4,8 or $16 \mu \mathrm{g}$ total protein was loaded onto sodium dodecyl sulfatepolyacrylamide gels, along with a molecular weight marker (Precision Plus Protein All Blue Standards; Bio-Rad) for resolution by electrophoresis at $100 \mathrm{~V}$ for $90 \mathrm{~min}$. Proteins were then transferred to polyvinylidene difluoride (PVDF) membranes for immunoblotting with the anti-AMHR2 chicken antibody ( $1: 25000$ dilution) after blocking with $0.1 \%$ Tween 20 and 5\% non-fat dry milk for $1 \mathrm{~h}$ at $25^{\circ} \mathrm{C}$. Membranes were incubated overnight at $4^{\circ} \mathrm{C}$ with the primary antibody, washed with $10 \mathrm{mM}$ Tris- $\mathrm{HCl}(\mathrm{pH} 7.6)$ containing $150 \mathrm{mM} \mathrm{NaCl}$ and $0.1 \%$ Tween 20 and then incubated with horseradish peroxidase (HRP)conjugated anti-chicken IgG goat antibody (Bethyl Laboratories; $1: 50000$ dilution) at $25^{\circ} \mathrm{C}$ for $1 \mathrm{~h}$. Protein bands were visualised using an ECL-Prime chemiluminescence kit (GE Healthcare) and CCD imaging system (Fujifilm). Previous studies using western blotting for AMHR2 reported that human and mouse AMHR2 are present as dimers, full-length monomers or cleaved monomers (Faure et al. 1996; Hirschhorn et al. 2015). Thus, we defined bovine AMHR2 bands based on mobility as one of these structure types. After antibodies had been removed from the PVDF membrane with stripping solution (Nacalai Tesque), the membrane was used for immunoblotting with the anti- $\beta$-actin mouse monoclonal antibody (A2228; 1:50000 dilution; Sigma-Aldrich).

\section{Fluorescent immunohistochemistry and confocal microscopic observation}

After storage in $4 \%$ paraformaldehyde dissolved in phosphatebuffered saline (PBS) at $4^{\circ} \mathrm{C}$ for $16 \mathrm{~h}$, the $\mathrm{AP}(n=5)$ or ovary $(n=5)$ tissue blocks were placed in $30 \%$ sucrose-PBS until the blocks were infiltrated with sucrose. The methods for immunofluorescence analysis of AP tissue have been described previously (Kadokawa et al. 2014). Briefly, we prepared 15- $\mu \mathrm{m}$ sagittal sections and mounted them on slides. The sections were treated with $0.3 \%$ Triton X-100 in PBS for 15 min, then incubated with $0.5 \mathrm{~mL}$ PBS containing $10 \%$ normal goat serum (Wako Pure Chemicals) for blocking for $1 \mathrm{~h}$. Incubation with a cocktail of primary antibodies (anti-GnRHR guinea pig antibody, anti-AMHR2 chicken antibody and either anti-LH $\beta$ or anti-FSH $\beta$ mouse antibody; all diluted $1: 1000$ ) for $12 \mathrm{~h}$ at $4^{\circ} \mathrm{C}$ was followed by incubation with a cocktail of fluorochromeconjugated secondary antibodies (Alexa Fluor 488 goat antichicken IgG, Alexa Fluor 546 goat anti-mouse IgG and Alexa Fluor 647 goat anti-guinea pig IgG; all from Thermo Fisher Scientific; all diluted $1 \mu \mathrm{g} \mathrm{mL}^{-1}$ ) and $1 \mu \mathrm{g} \mathrm{mL}^{-1} 4^{\prime}, 6^{\prime}$-diamino2-phenylindole (DAPI; Wako Pure Chemicals) for $2 \mathrm{~h}$ at room 
temperature. In addition, $15-\mu \mathrm{m}$ ovary sections were prepared, incubated with anti-AMHR2 chicken antibody ( $1: 1000$ dilution) and then incubated with $1 \mu \mathrm{g} \mathrm{mL}^{-1}$ Alexa Fluor 488 goat anti-chicken IgG and DAPI as positive controls to verify the antiAMHR2 antibody.

The stained sections on slides were observed under a confocal microscope (LSM710; Carl Zeiss) equipped with diode $(405 \mathrm{~nm})$, argon $(488 \mathrm{~nm}), \mathrm{HeNe}(533 \mathrm{~nm})$ and $\mathrm{HeNe}(633 \mathrm{~nm})$ lasers. Images obtained by fluorescence microscopy were scanned with a $\times 40$ or $\times 63$ oil-immersion objective and recorded by a CCD camera system controlled by ZEN2012 black edition software (Carl Zeiss). GnRHR, AMHR2 and LH $\beta$ or FSH $\beta$ localisation was examined in confocal images of tripleimmunolabelled specimens. In the confocal images obtained after immunohistochemical analysis, the GnRHR is shown in green, AMHR2 is shown in red and LH $\beta$ or FSH $\beta$ are shown in light blue. Therefore, the yellow colouration on the surface of light blue-coloured cells indicates the colocalisation of AMHR2 and GnRHR. The percentage of AMHR2 single (red)-labelled light blue-coloured cells or the percentage of double (yellow)labelled light blue-coloured cells among all the AMHR2-positive light blue-coloured cells (sum of the numbers of red- and yellowlabelled light blue-coloured cells) was determined from 12 representative confocal images per pituitary gland. Moreover, the percentage of GnRHR single (green)-labelled light bluecoloured cell, or the percentage of double (yellow)-labelled light blue-coloured cells among all the GnRHR-positive light bluecoloured cells (sum of the number of green- and yellow-labelled light blue-coloured cells) was determined from 12 representative confocal images per pituitary gland. To verify the specificity of the signals, we included several negative controls in which the primary antiserum had been omitted or preabsorbed with $5 \mathrm{nM}$ of the same antigen peptide, or in which normal chicken IgG (Wako Pure Chemicals) was used instead of the primary antibody.

\section{AP cell culture and immunocytochemical analysis of cells}

AP cells from five heifers were dispersed enzymatically using the method of Suzuki et al. (2008), and cell viability was confirmed to be $>90 \%$ by Trypan blue exclusion. Total cell yield was $19.8 \pm 0.8 \times 10^{6}$ (mean \pm s.e.m.) cells per pituitary gland. The dispersed cells were then suspended in Dulbecco's modified Eagle's medium (DMEM; Thermo Fisher Scientific) containing $1 \times$ non-essential amino acids (Thermo Fisher Scientific), $100 \mathrm{U} \mathrm{mL}^{-1}$ penicillin, $50 \mu \mathrm{g} \mathrm{mL}^{-1}$ streptomycin, $10 \%$ horse serum (Thermo Fisher Scientific) and 2.5\% fetal bovine serum (Thermo Fisher Scientific). The cells $\left(2.5 \times 10^{5}\right.$ cells $\mathrm{mL}^{-1}$; total $=0.15 \mathrm{~mL}$ per lane) were cultured in the culture medium at $37^{\circ} \mathrm{C}$ in $5 \% \mathrm{CO}_{2}$ for $82 \mathrm{~h}$ in a microscopy chamber $(\mu$-Slide VI 0.4 ; Ibidi). AP cells were cultured for $82 \mathrm{~h}$ ( 3.5 days), as described previously (Hashizume et al. 2003, 2009; Kadokawa et al. 2008, 2014; Nakamura et al. 2015). Recombinant human activin A (final concentration $10 \mathrm{ng} \mathrm{mL}^{-1}$; R\&D Systems) was supplied to stimulate FSH synthesis $24 \mathrm{~h}$ before fixation. Mature activin A of bovine (NP_776788.1) and ovine (NP_001009458.1) has 100\% homology with that of humans activin A (CAA40805.1) and 24-h culture with the same concentration of the same recombinant human activin A product stimulated FSH expression in cultured ovine AP cells (Young et al. 2008).
Cultured cells were either fixed using 4\% paraformaldehyde for $3 \mathrm{~min}$ followed by $0.1 \%$ Triton X-100 treatment for $1 \mathrm{~min}$ (PFA-Triton method) or fixed for 2 min with CellCover (Anacyte Laboratories), instead of 4\% PFA, without subsequent Triton X-100 treatment (CellCover method), as described by Kadokawa et al. (2014). Briefly, one of these two methods was used to treat the cells attached to the bottom of the microscopy chamber. For the PFA-Triton method, the fixed cells were incubated with $0.1 \mathrm{~mL}$ of the same cocktail of primary antibodies for $2 \mathrm{~h}$ at room temperature. Incubation with Triton X-100 allowed both anti-GnRHR and anti-AMHR2 antibodies to bind to target proteins in the cytoplasm and at the cell surface. In the case of the CellCover method, the fixed cells were incubated for $2 \mathrm{~h}$ at room temperature with guinea pig antiGnRHR and chicken anti-AMHR2 only (both 1: 1000 dilution). The cells were not treated with Triton X-100, so the antibodies bound only to the extracellular domains of the respective receptors in most cells, although some cytoplasmic labelling occurred in broken cells. For both the PFA-Triton and CellCover methods, cells were incubated with fluorochrome-conjugated secondary antibody cocktail and DAPI, and subjected to confocal microscopy to produce fluorescence micrographs and differential interference contrast (DIC) images on a single plane. Signal specificity was confirmed using negative controls in which the primary antiserum was omitted or preabsorbed with $5 \mathrm{nM}$ antigen peptide, or in which the normal chicken IgG replaced the primary antibody. Eight randomly selected images of cells prepared by the CellCover method were analysed for colocalisation using ZEN 2012 black edition software (Carl Zeiss) to calculate overlap coefficients (Manders et al. 1993) for the Alexa Fluor 488 and Alexa Fluor 647 fluorophores.

\section{Pituitary cell culture and analysis of the effects of $\mathrm{AMH}$ on $\mathrm{LH}$ and FSH secretion}

The AP cells derived from eight heifers were prepared using the

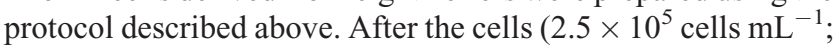
total $0.3 \mathrm{~mL}$ ) had been plated in 48 -well culture plates (Sumitomo Bakelite), they were maintained at $37^{\circ} \mathrm{C}$ in a humidified atmosphere of $5 \% \mathrm{CO}_{2}$ for $82 \mathrm{~h}$. Recombinant human activin $\mathrm{A}$ (final concentration $10 \mathrm{ng} \mathrm{mL}^{-1}$ ) was supplied to stimulate $\mathrm{FSH}$ synthesis $24 \mathrm{~h}$ before the AMH test.

In the test to evaluate the effects of AMH in the absence of $\mathrm{GnRH}$, the old medium was replaced by $295 \mu \mathrm{L}$ DMEM containing $0.1 \%$ bovine serum albumin (BSA) and $10 \mathrm{ng} \mathrm{mL}^{-1}$ activin $\mathrm{A}$ and cells were incubated for $2 \mathrm{~h}$. Cells were treated with the addition of either $5 \mu \mathrm{L}$ DMEM alone or $5 \mu \mathrm{L}$ DMEM containing different concentrations of human recombinant AMH (R\&D Systems; final concentration 0, 1, 10, 100 or $\left.1000 \mathrm{pg} \mathrm{mL}^{-1} \mathrm{AMH}\right)$.

The bioactive region in the C-terminal region of mature AMH (Belville et al. 2004) of bovines (NP_776315.1) and goat (XP_017906255.1) has 96\% homology with that of human mature AMH (NP_000470.2), and the same recombinant human $\mathrm{AMH}$ product has a biological effect on goat follicles (Rocha et al. 2016).

After incubation for a further $2 \mathrm{~h}$, the medium from each well was collected for radioimmunoassay (RIA) analysis of LH and FSH levels. In a previous study, we found that the physiological 
concentration of AMH in blood in Japanese Black cows ranged between 5 and $300 \mathrm{pg} \mathrm{mL}^{-1}$ (Koizumi and Kadokawa 2017). The concentrations of AMH used in the present study were based on these findings.

In experiments evaluating the effects of $\mathrm{AMH}$ in the presence of GnRH, the old medium was replaced with $290 \mu \mathrm{L}$ DMEM containing $0.1 \% \mathrm{BSA}$ and $10 \mathrm{ng} \mathrm{mL}^{-1}$ activin $\mathrm{A}$ and cells were incubated at $37^{\circ} \mathrm{C}$ for $2 \mathrm{~h}$. Cells were pretreated by the addition of $5 \mu \mathrm{L}$ DMEM alone or $5 \mu \mathrm{L}$ DMEM containing different concentrations $\left(0,60,600,6000\right.$ and $\left.60000 \mathrm{pg} \mathrm{mL}^{-1}\right)$ of human recombinant $\mathrm{AMH}$. Cells were incubated with gentle shaking for 5 min and then treated with $5 \mu \mathrm{L}$ of $60 \mathrm{nM}$ GnRH (Peptide Institute) dissolved in DMEM for $2 \mathrm{~h}$ in order to stimulate $\mathrm{LH}$ and FSH secretion. The pretreatment plus the GnRH treatment yielded a final concentration of $0,1,10,100$, or $1000 \mathrm{pg} \mathrm{mL}^{-1}$ AMH. The final concentration of GnRH was $1 \mathrm{nM}$ in all treatments (Kadokawa et al. 2014), except in the control. Control wells were treated with $5 \mu \mathrm{L}$ DMEM, but were not incubated with GnRH. 'GnRH' wells were pretreated with $5 \mu \mathrm{L}$ DMEM for $5 \mathrm{~min}$ and were then incubated with GnRH for $2 \mathrm{~h}$. After incubation for $2 \mathrm{~h}$, the medium from each well was collected for LH and FSH RIA.

\section{RIA to measure gonadotrophin concentrations in culture media}

The concentration of LH was measured in duplicate samples of culture media by double-antibody RIA using ${ }^{125}$ I-labelled bovine (b) LH and anti-ovine (o) LH-antiserum (AFP11743B and AFP192279 respectively; National Hormone and Pituitary Program of the National Institute of Diabetes and Digestive and Kidney Diseases (NIDDK)). The limit of detection was $0.40 \mathrm{ng} \mathrm{mL}^{-1}$. At $2.04 \mathrm{ng} \mathrm{mL}^{-1}$, the intra- and interassay CVs were $3.6 \%$ and $6.2 \%$ respectively. The concentration of FSH was measured in duplicate samples of culture media by doubleantibody RIA using ${ }^{125} \mathrm{I}$-labelled bFSH, reference-grade bFSH and anti-oFSH antiserum (AFP5318C, AFP5346D and AFPC5288113 respectively; NIDDK). The limit of detection was $0.20 \mathrm{ng} \mathrm{mL}^{-1}$. At $4.00 \mathrm{ng} \mathrm{mL}^{-1}$, the intra- and interassay CVs were $4.3 \%$ and $7.1 \%$ respectively.

\section{Statistical analysis}

The significance of differences in LH or FSH concentrations was analysed by one-factor analysis of variance (ANOVA) followed by post hoc comparisons using Fisher's protected least significant difference (PLSD) test using StatView version 5.0 for Windows (SAS Institute). The level of significance was set at $P<0.05$. Data are expressed as the mean \pm s.e.m.

\section{Results}

Expression of AMHR2 mRNA in the AP of postpubertal heifers

The expected PCR products (sizes 340, 320 and $277 \mathrm{bp}$ ) were observed in the agarose gel after electrophoresis (Fig. 1). Homology searching in the gene databases for the obtained sequences of amplified products using the first, second and third primer pairs revealed that the best match alignment was bovine AMHR2 (NM_001205328.1), which had a query coverage of

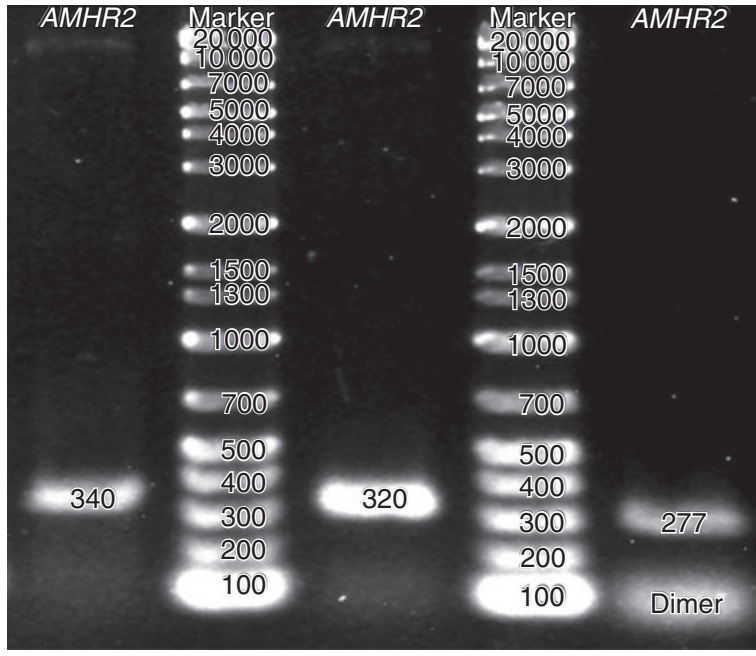

Fig. 1. Expression of anti-Müllerian hormone (AMH) receptor type 2 (AMHR2) mRNA, as detected by reverse transcription-polymerase chain reaction. Electrophoresis of polymerase chain reaction (PCR)-amplified DNA products using one of three pairs of primers for bovine AMHR2 and cDNA derived from anterior pituitary (AP) of postpubertal heifers. The lanes labelled AMHR2 demonstrate that the DNA products obtained were of the size that had been expected, namely 340,320 and $277 \mathrm{bp}$. The other two lanes labelled 'Marker' are the DNA markers.

$100 \%$, an e-value of 0.0 and a maximum alignment identity of $99 \%$. No other bovine gene was found to have a homology for the obtained sequences of amplified products, leading to the conclusion that the sequences of the amplified products were identical with the sequence of bovine $A M H R 2$.

\section{Western blotting for AMHR2}

The presence of AMHR2 in the AP and ovarian tissue was analysed by western blot, using anti-AMHR2 antibody (Fig. 2). The anti-AMHR2 antibody revealed similar bands in the two tissues, with few differences (Fig. 2a). The major difference was that the intensity of the bands was weaker in AP than ovarian tissue. Nevertheless, $\beta$-actin bands showed weaker staining in AP tissue than ovarian tissue (Fig. 2b). Finally, another difference was that the full-length monomer in the ovary appeared as a single band, whereas in AP cells it appeared as a doublet (Fig. 2a). No bands were observed in the negative control membranes, in which the primary antiserum was preabsorbed with the antigen peptide.

\section{Immunofluorescence analysis of AMHR2 expression in bovine granulosa cells}

Fig. 3 shows results of immunofluorescence staining in granulosa cells of small $(\sim 5 \mathrm{~mm})$ follicles in the ovary tissues of postpubertal heifers. Strong AMHR2 staining appeared to be aggregated, not evenly dispersed.

\section{Immunofluorescence analysis of AMHR2 expression in bovine AP tissue}

Expression of LH $\beta, F S H \beta$, GnRHR and AMHR2 in bovine AP tissue was investigated by immunohistochemistry (Fig. 4). 
(a)

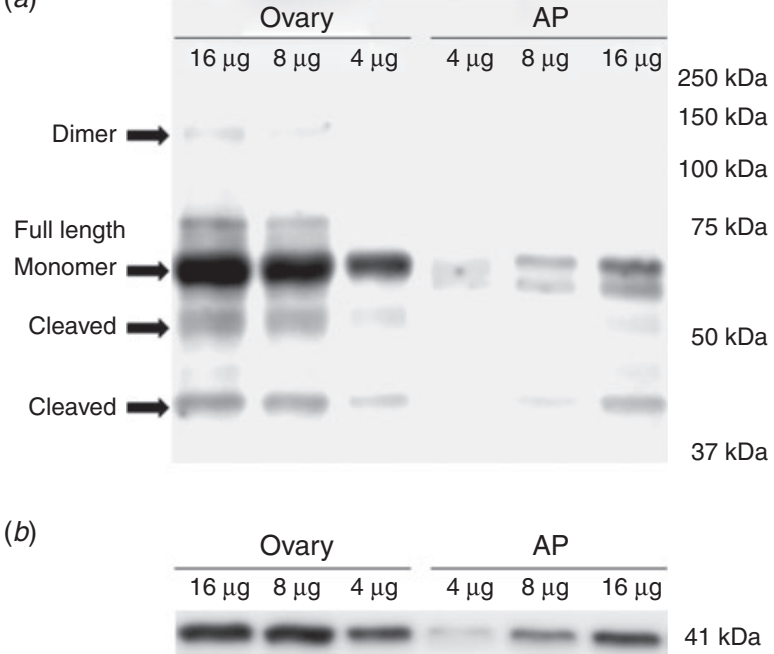

Fig. 2. Results of western blotting using extracts 4,8 or $16 \mu \mathrm{g}$ total protein from the anterior pituitary (AP) or ovary of postpubertal heifers and $(a)$ antiMüllerian hormone receptor type 2 (AMHR2) antibody or (b) anti- $\beta$-actin antibody. Bovine AMHR2 bands were defined as dimers, full-length monomers or cleaved monomers based on size, according to previous studies using western blotting for human and mouse AMHR2 (Faure et al. 1996; Hirschhorn et al. 2015).

AMHR2 and GnRHR colocalised in the majority of both LH $\beta$ positive (Fig. $4 a$ ) and FSH $\beta$-positive (Fig. $4 b$ ) cells. The focus depth of the high magnification lens used in the present study is thin, thus the best focus for GnRHR and AMHR2 on plasma membrane was quite different from the best focus for both the nucleus and cytoplasmic LH $\beta$ or FSH $\beta$. Thus, we know that both membrane receptors are on the cell surface. The percentage of single- and double-labelled AMHR2- and GnRHR-positive cells was determined from 12 representative confocal images per pituitary gland. In each pituitary gland, there was an average of $52.4 \pm 2.4$ GnRHR-positive cells, $44.6 \pm 1.2$ AMHR2-positive cells and $33.6 \pm 1.3$ double-positive cells; $64.5 \pm 3.2 \%$ of GnRHR-positive cells were AMHR2 positive, whereas $78.4 \pm 1.8 \%$ of AMHR2-positive cells were GnRHR positive.

\section{AMHR2 and GnRHR aggregate on the surface of cultured AP cells}

In the AP cells prepared by the CellCover method, AMHR2 aggregated on the surface of GnRHR-positive cells (Fig. 5). The overlap coefficient between AMHR2 and GnRHR was $0.76 \pm 0.05$ on the cell surface of cultured AP cells.

\section{AMHR2 expression in cultured gonadotrophs}

Among AP cells prepared by the PFA-Triton method, AMHR2 was observed in both LH $\beta$-positive and FSH $\beta$-positive cells (Fig. 6).

\section{Effects of AMH on gonadotrophin secretion from} cultured AP cells

Fig. 7 shows the effects of various concentrations of AMH on LH secretion from AP cells derived from postpubertal heifers
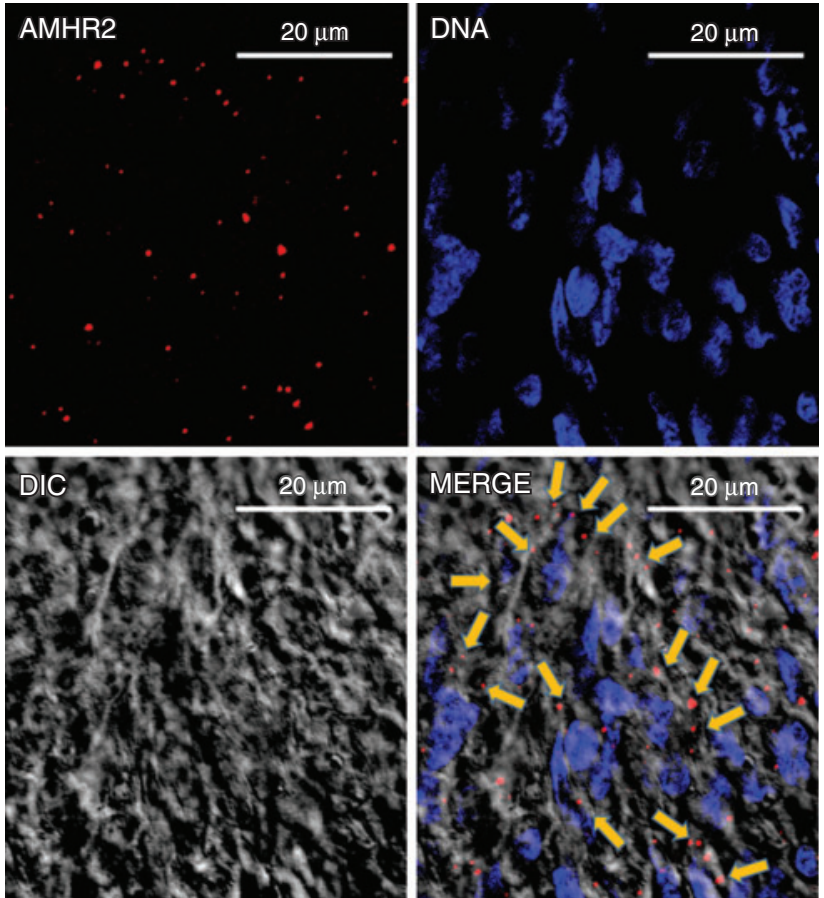

Fig. 3. Fluorescence immunocytochemistry was used to confirm the expression of anti-Müllerian hormone receptor type 2 (AMHR2) on the surface of granulosa cells of small $(\sim 5 \mathrm{~mm})$ follicles in the ovaries of postpubertal heifers. Images were captured by laser confocal microscopy for AMHR2 (red), DNA (dark blue) and differential interference contrast (DIC). Strong AMHR2 staining appeared to be aggregated (arrows), not evenly dispersed.

cultured in the absence (Fig. 7a) or presence (Fig. 7b) of GnRH. In the absence of GnRH (Fig. 7a), 100 and $1000 \mathrm{pg} \mathrm{mL}^{-1} \mathrm{AMH}$ increased $(P<0.05)$ LH secretion compared with control (medium LH concentration of control group was 17.6土 $2.4 \mathrm{ng} \mathrm{mL}^{-1}$ ). Conversely, AMH had no effect on $\mathrm{GnRH}-$ induced LH secretion (Fig. 7b).

Fig. 8 shows the effects of different concentrations of AMH on FSH secretion from AP cells derived from postpubertal heifers cultured in the absence (Fig. $8 a$ ) or presence (Fig. 8b) of GnRH. The effect of different concentrations of AMH was significant $(P<0.05)$ in the absence of GnRH (Fig. $8 a)$. FSH concentrations were significantly $(P<0.05)$ higher in wells with 10,100 and $1000 \mathrm{pg} \mathrm{mL}^{-1} \mathrm{AMH}$, but not $1 \mathrm{pg} \mathrm{mL}^{-1}$ $\mathrm{AMH}$, than those without AMH $\left(8.4 \pm 1.2 \mathrm{ng} \mathrm{mL}^{-1}\right)$. The effects of different concentrations of AMH were significant $(P<0.05)$ in the presence of GnRH (Fig. 8b). FSH concentrations in the medium of GnRH-containing wells were higher $(P<0.05)$ than those in the medium of control wells. AMH at 1 or $10 \mathrm{pg} \mathrm{mL}^{-1}$ had no effect on GnRH-induced FSH secretion. However, 100 and $1000 \mathrm{pg} \mathrm{mL}^{-1}$ AMH suppressed GnRHinduced FSH secretion $(P<0.05$ for both).

\section{Discussion}

To the best of our knowledge, the present study is the first to report that AP cells from ruminants express AMHR2 and that 
(a)
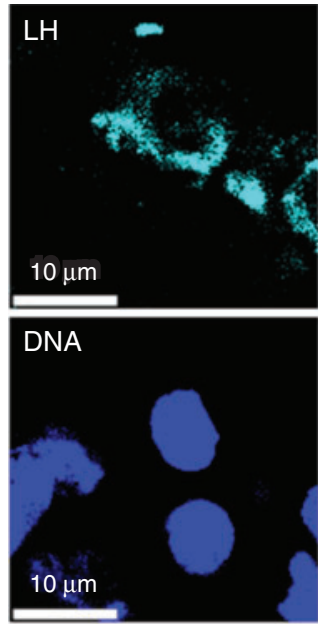

(b)
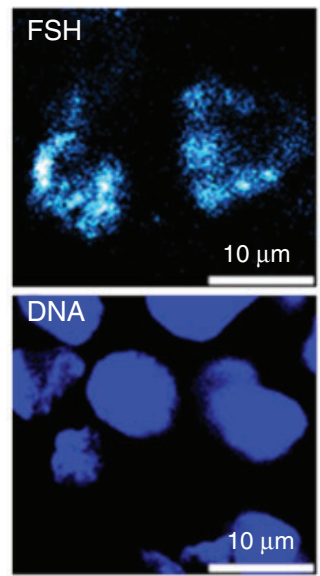
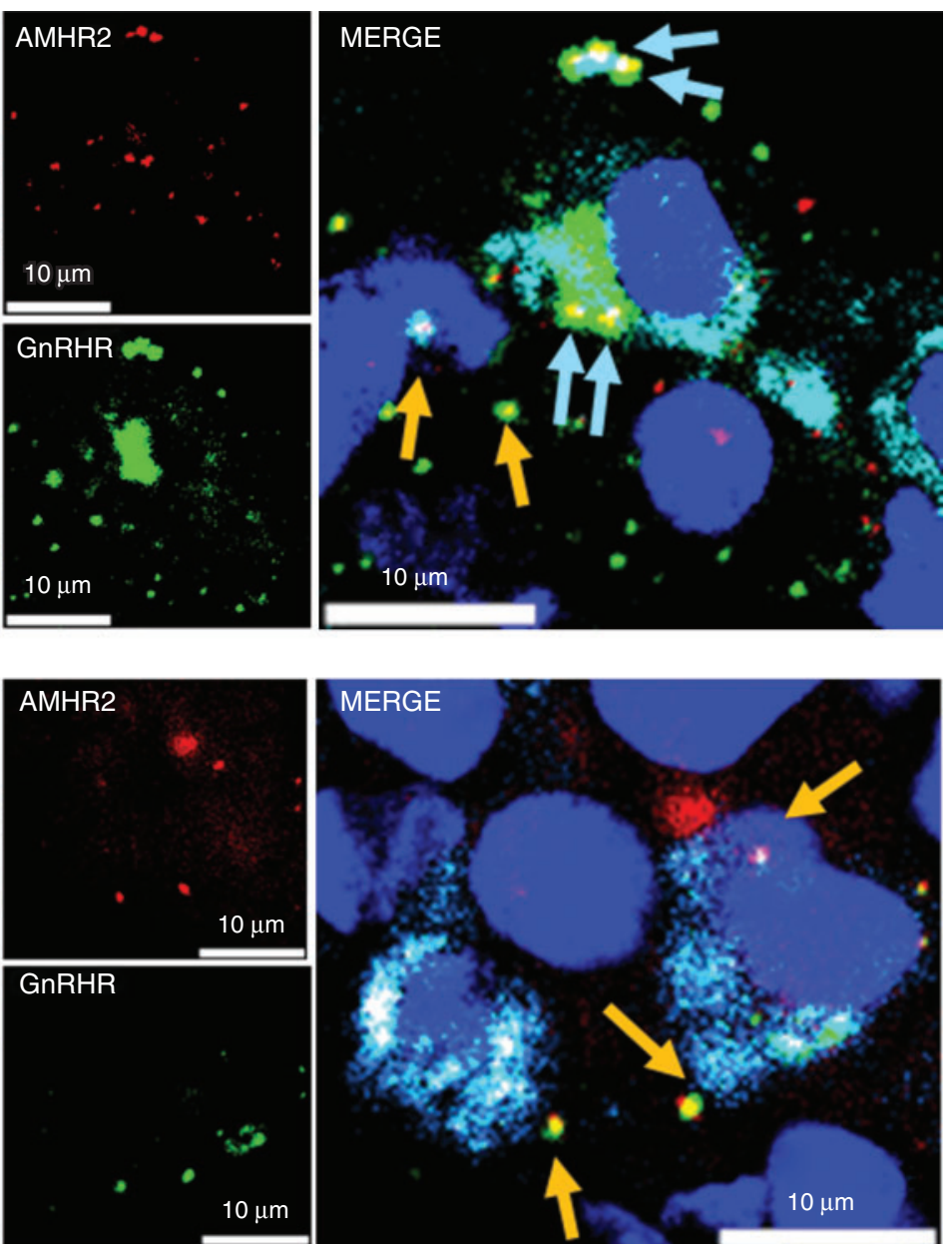

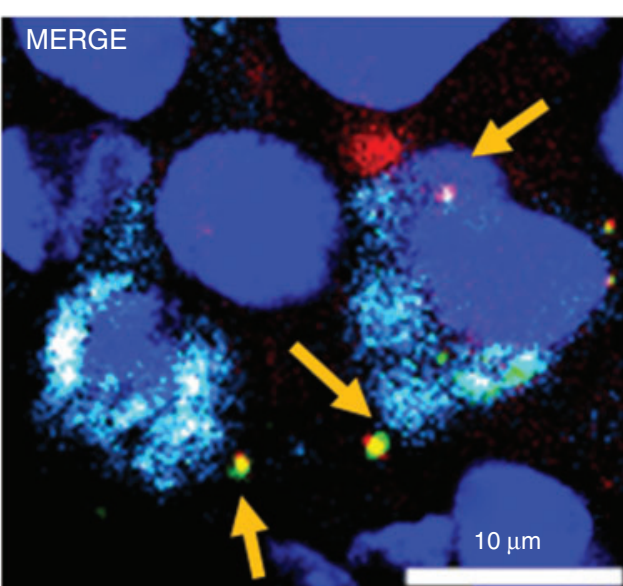

Fig. 4. Triple-fluorescence immunohistochemistry of anterior pituitary (AP) tissue of postpubertal heifers for antiMüllerian hormone receptor type 2 (AMHR2), gonadotrophin-releasing hormone receptor (GnRHR) and either (a) LH or (b) FSH. Images were captured by laser confocal microscopy for AMHR2 (red), GnRHR (green) and LH or FSH (light blue) with counterstaining by $4^{\prime}, 6^{\prime}$-diamidino-2-phenylindole (DAPI; dark blue). Yellow indicates the colocalisation of AMHR2 and GnRHR on the surface of LH-positive cells (blue arrows) and FSH-positive cells (orange arrows). Both AMHR2 and GnRHR appeared to be aggregated, not evenly dispersed. Note that the focus depth of the high magnification lens is thin; thus, the best focus for the membrane receptors was quite different from the best focus for the nucleus and cytoplasmic LH. Therefore, these images were taken using the best focus for the membrane receptors while using strong laser power and strong charge-coupled device sensitivity for DAPI and cytoplasmic LH.

AMH significantly affects LH and FSH secretion from AP cells. Fluorescent immunohistochemistry using the anti-AMHR2 antibody showed a strong signal located on the surface of granulosa cells in small antral follicles, where $A M H R 2$ mRNA is expressed (Poole et al. 2016). Therefore, the anti-bovine AMHR2 is the first developed tool that can be used for immunohistochemistry in bovine samples.

In the present study, treatment with $10-1000 \mathrm{pg} \mathrm{mL}^{-1} \mathrm{AMH}$ stimulated FSH secretion in the absence of GnRH. This finding is in agreement with in vivo experiments on rats, where AMH stimulates the secretion and expression of FSH (Garrel et al. 2016). These data suggest that AMH may bind with AMHR2 to increase FSH secretion from gonadotrophs in ruminants as well. Garrel et al. (2016) recently reported that AMH increases both
FSH $\beta$ expression and phosphorylates SMAD1/5/8 in L $\beta$ T2 cells, but such increases are blocked by GnRH. In the present study, 1-10 $\mathrm{pg} \mathrm{mL}^{-1} \mathrm{AMH}$ did not change GnRH-stimulated FSH secretion; however, $100-1000 \mathrm{pg} \mathrm{mL}^{-1}$ AMH suppressed GnRHstimulated FSH secretion. Therefore, further studies are required to clarify the molecular mechanisms controlling FSH secretion from ruminant gonadotrophs by $\mathrm{AMH}$ and $\mathrm{GnRH}$, especially whether the SMAD1/5/8 pathways have important roles.

Multiparous (third parity or higher) Japanese Black cows have significantly higher blood AMH concentrations $\left(100 \mathrm{pg} \mathrm{mL}^{-1}\right)$ than primiparous cows $\left(1-10 \mathrm{pg} \mathrm{mL}^{-1}\right)$ throughout the postpartum period (Koizumi and Kadokawa 2017). In addition the number of days from parturition to first ovulation postpartum is higher in multiparous than 

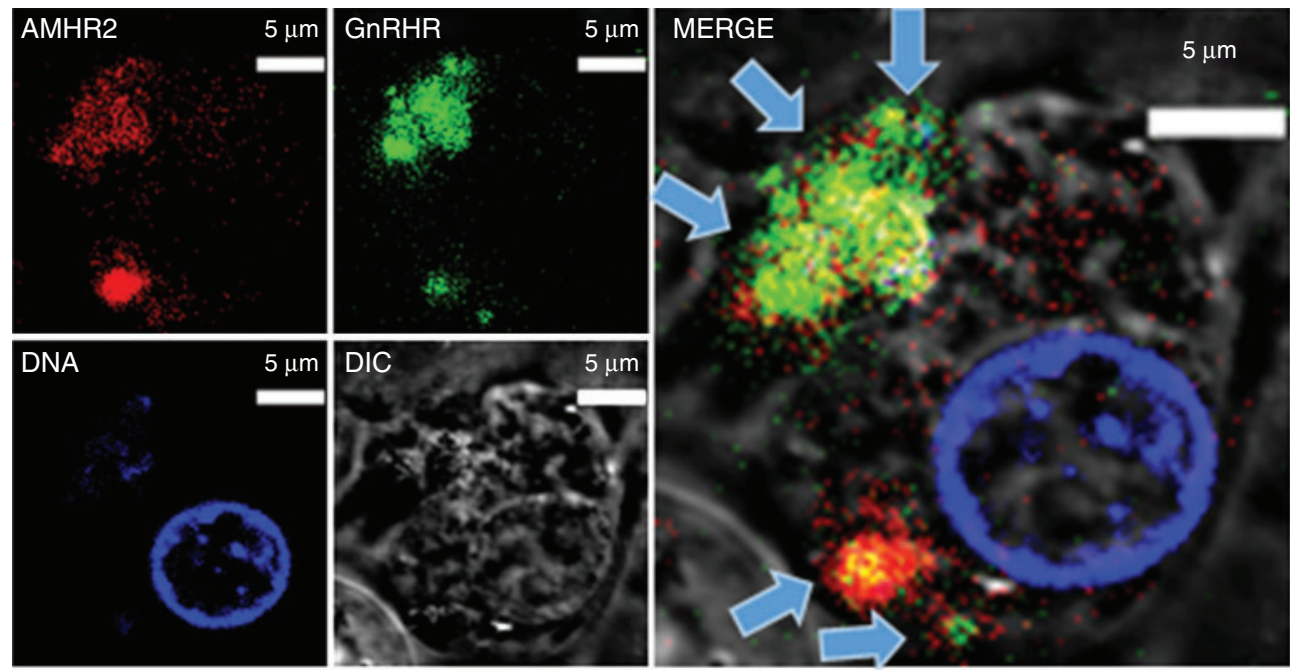

Fig. 5. Fluorescence immunocytochemistry was used to confirm the colocalisation (yellow in the merge panel) of anti-Müllerian hormone receptor type 2 (AMHR2) and gonadotrophin-releasing hormone receptor (GnRHR) on the surface of cultured anterior pituitary (AP) cells (prepared by the CellCover method; see text for details) of postpubertal heifers. Images were captured by laser confocal microscopy for AMHR2 (red), GnRHR (green), DNA (dark blue) and differential interference contrast (DIC) on cultured AP cells that were not treated with Triton X-100 for antibody penetration. Thus, the antibody could only bind AMHR2 and GnRHR on the surface of gonadotrophs. The blue arrows indicate the colocalisation of aggregated GnRHR and aggregated AMHR2.

primiparous Japanese Black cows (Koizumi and Kadokawa 2017). Therefore, the suppressive effect of $100-1000 \mathrm{pg} \mathrm{mL}^{-1}$ of $\mathrm{AMH}$ on GnRH-stimulated FSH secretion may have an important role in the follicular growth and delayed first ovulation postpartum in multiparous cows.

Intraperitoneal injection with AMH increases FSH concentrations in blood collected $18 \mathrm{~h}$ later, but only in prepubertal female rats (Garrel et al. 2016). In contrast, the present study showed a significant effect of AMH on FSH secretion from the AP of postpubertal heifers in vitro. Therefore, further studies are required to clarify whether there are any differences in AMH effects on FSH secretion among species.

Unlike the hypothalamus, the pituitary gland is located outside the blood-brain barrier (Nussey and Whitehead 2001); therefore, the AMHR2 on gonadotrophs may bind AMH secreted from preantral and small antral follicles. The findings of the present study suggest that AMH, like other members of the TGF $\beta$ family, such as inhibin and activin (Kushnir et al. 2017), can affect FSH secretion from gonadotrophs. However, little is known about the changes that occur in blood AMH concentrations during the oestrous cycle in ruminants (Pfeiffer et al. 2014; Koizumi and Kadokawa 2017). The blood AMH concentration is affected by age and parity (Koizumi and Kadokawa 2017); however, the concentration may not show considerable changes during the oestrous cycle in ruminants in vivo (Pfeiffer et al. 2014; Koizumi and Kadokawa 2017). Therefore, we must be cautious before concluding that $\mathrm{AMH}$ makes a considerable contribution to the control of LH and FSH secretion from gonadotrophs in vivo.

The results of the present study suggest that preantral and small antral follicles may control gonadotrophin secretion from the AP in postpubertal heifers. Conversely, FSH suppresses
AMH secretion from bovine granulosa cells (Rico et al. 2011). Therefore, there may be feedback mechanisms between gonadotrophs and granulosa cells in preantral and small antral follicles. AMH locally decreases the sensitivity of FSH in follicles in many species, including the mouse and sheep (Durlinger et al. 2001; Campbell et al. 2012; Visser and Themmen 2014). Recently, Ilha et al. (2016) reported that $A M H$ mRNA levels decrease in both dominant and subordinate follicles during follicular deviation in cows. Thus, both dominant and subordinate follicles become more sensitive to FSH and can be recruited to enter the pool of follicles that may then become dominant (Visser and Themmen 2014). Therefore, AMH may have an important role in both the ovary and gonadotrophs during follicular selection in monovulatory species.

Gonadotrophs are a heterogeneous cell population comprising LH and FSH monohormonal and bihormonal subsets in rats, equines and bovines (Townsend et al. 2004; Pals et al. 2008; Kadokawa et al. 2014). In the present study, fluorescent immunohistochemistry showed AMHR2 expression in LH $\beta$-positive cells as well as FSH $\beta$-positive cells. Furthermore, 100 and $1000 \mathrm{pg} \mathrm{mL}^{-1} \mathrm{AMH}$ only weakly stimulated $\mathrm{LH}$ secretion. Therefore, AMH may control also LH secretion, but weakly. Intraperitoneal injection with AMH increases FSH concentrations in the blood collected $18 \mathrm{~h}$ later in rats; however, $\mathrm{AMH}$ injection does not significantly increase LH concentrations in the same blood samples (Garrel et al. 2016). Therefore, the effect of $\mathrm{AMH}$ on LH secretion in vivo may not become significant.

It is well known that G-protein-coupled receptor (GPCR) can form functionally active homomers and heteromers with different receptors (Ritter and Hall 2009). We found a strong positive overlap coefficient between AMHR2 and GnRHR on the cell surface. This overlap coefficient was greater than that reported 

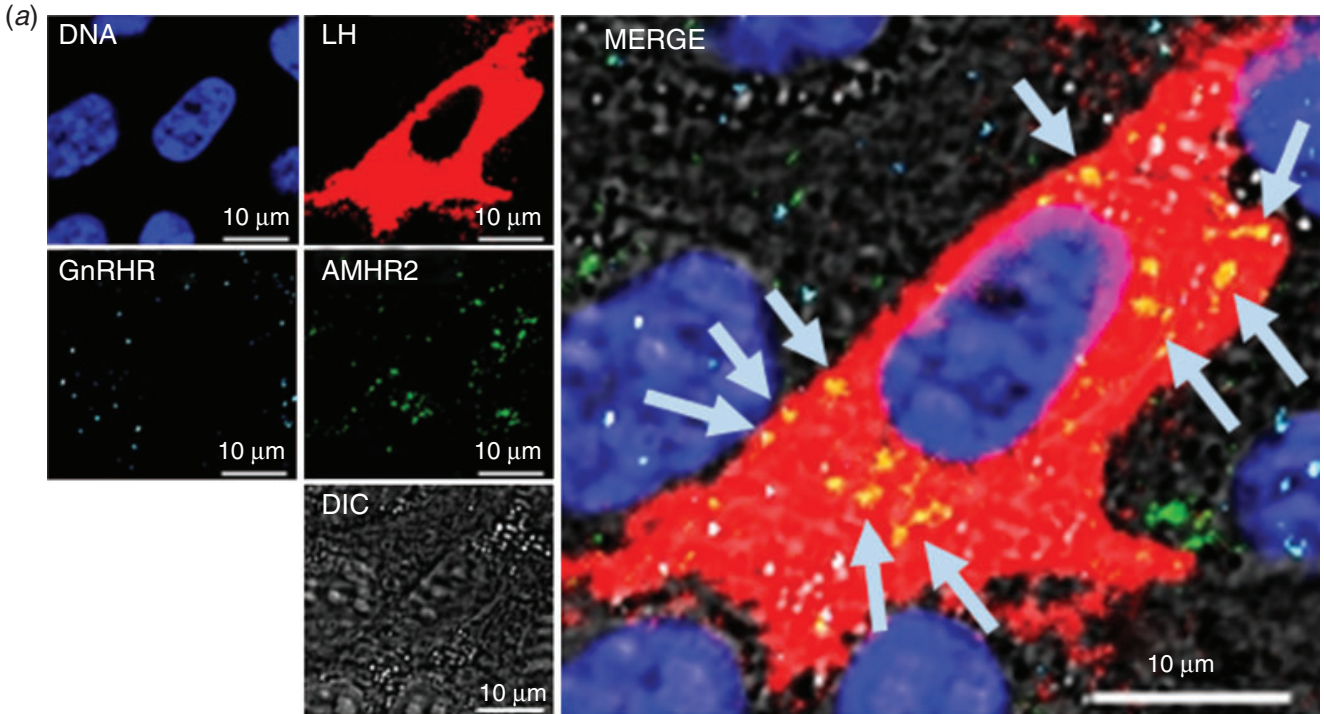

(b)

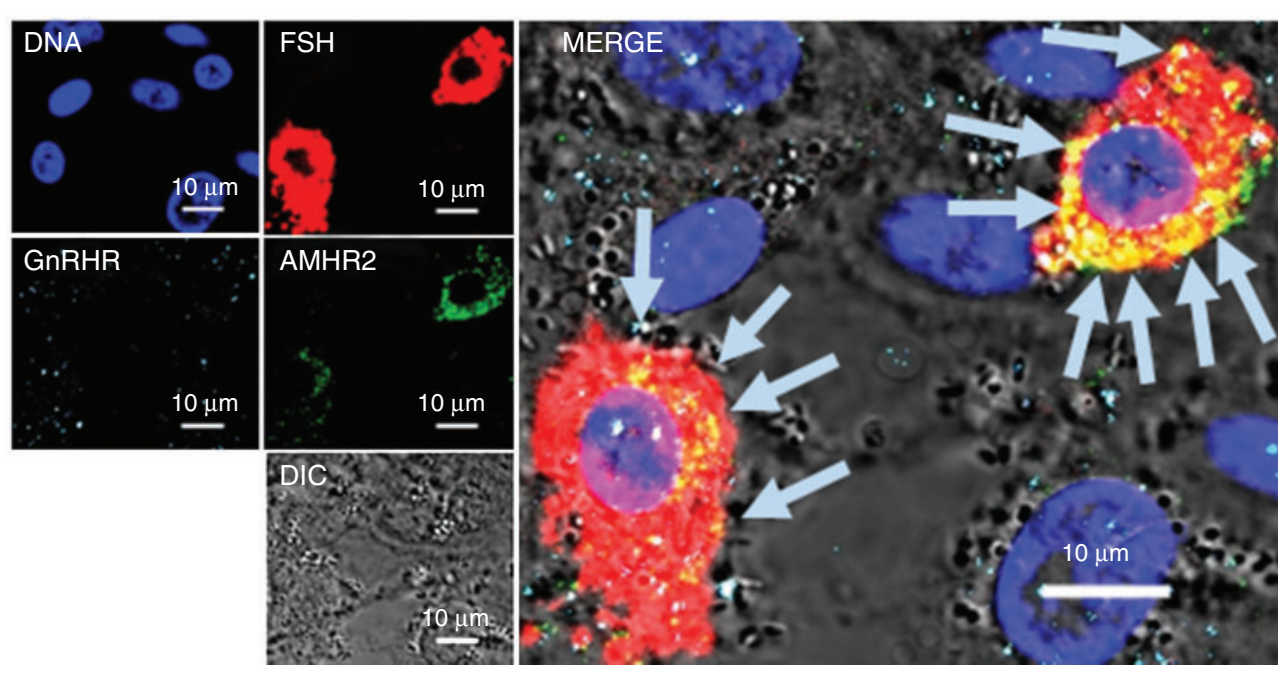

Fig. 6. Triple-fluorescence immunocytochemistry of cultured anterior pituitary (AP) cells (prepared by the paraformaldehyde (PFA)-Triton method; see text for details) of postpubertal heifers for anti-Müllerian hormone receptor type 2 (AMHR2), gonadotrophin-releasing hormone receptor (GnRHR) and either (a) LH or (b) FSH. Images were captured by laser confocal microscopy for AMHR2 (green), GnRHR (light blue) and LH or FSH (red) with counterstaining by $4^{\prime}, 6^{\prime}$ diamidino-2-phenylindole (DAPI; dark blue). Yellow (arrows) indicates the colocalisation of AMHR2 and LH of FSH in (a) LH- and (b) FSH-positive cells. These images were taken using the best focus for the membrane receptors while using strong laser power and strong charge-coupled device sensitivity for DAPI and cytoplasmic LH. Note that the cells prepared by the PFA-Triton method are thinner than those prepared by the CellCover method.

between GnRHR and flotillin-1 in cultured L $\beta$ T2 cells $(0.50$; Wehmeyer et al. 2014) and similar to that we found previously between GnRHR and GPR61 (0.71; Pandey et al. 2017) and GPR153 (0.75; Pandey et al. 2018) in bovine gonadotrophs. Heterodimerisation among paralogues of GnRHRs of a protochordate results in the modulation of ligand-binding affinity, signal transduction and internalisation (Satake et al. 2013). Thus, it is possible that AMHR2 forms a heteromer, affecting ligand-binding affinity, signal transduction and internalisation of GnRHR, and thus the synthesis and secretion of LH and FSH in the AP of vertebrates. Furthermore, a recent study (Hossain et al. 2016) suggested that GPR61 forms heteromers with other
GPCRs. Therefore, further studies are required to clarify whether GnRHR forms heteromers with GPR61, GPR153 and AMHR2.

In the present study we observed multiple, not single, bands of AMHR2 in western blotting analysis, which has been reported previously. For example, Faure et al. (1996) reported three bands $(82,73$ and $63 \mathrm{kDa})$ of dimers, full-length monomers and cleaved monomers. Hirschhorn et al. (2015) reported more bands $(\sim 58, \sim 69$ and $\sim 71 \mathrm{kDa})$ of dimers, full-length monomers and cleaved monomers. AMHR2 is present as dimers, full-length monomers and cleaved monomers in bovine ovaries and APs. Treatment with $\mathrm{N}$-glycosidase F showed a further two bands ( 68 and $61 \mathrm{kDa}$ ) by cutting down by 

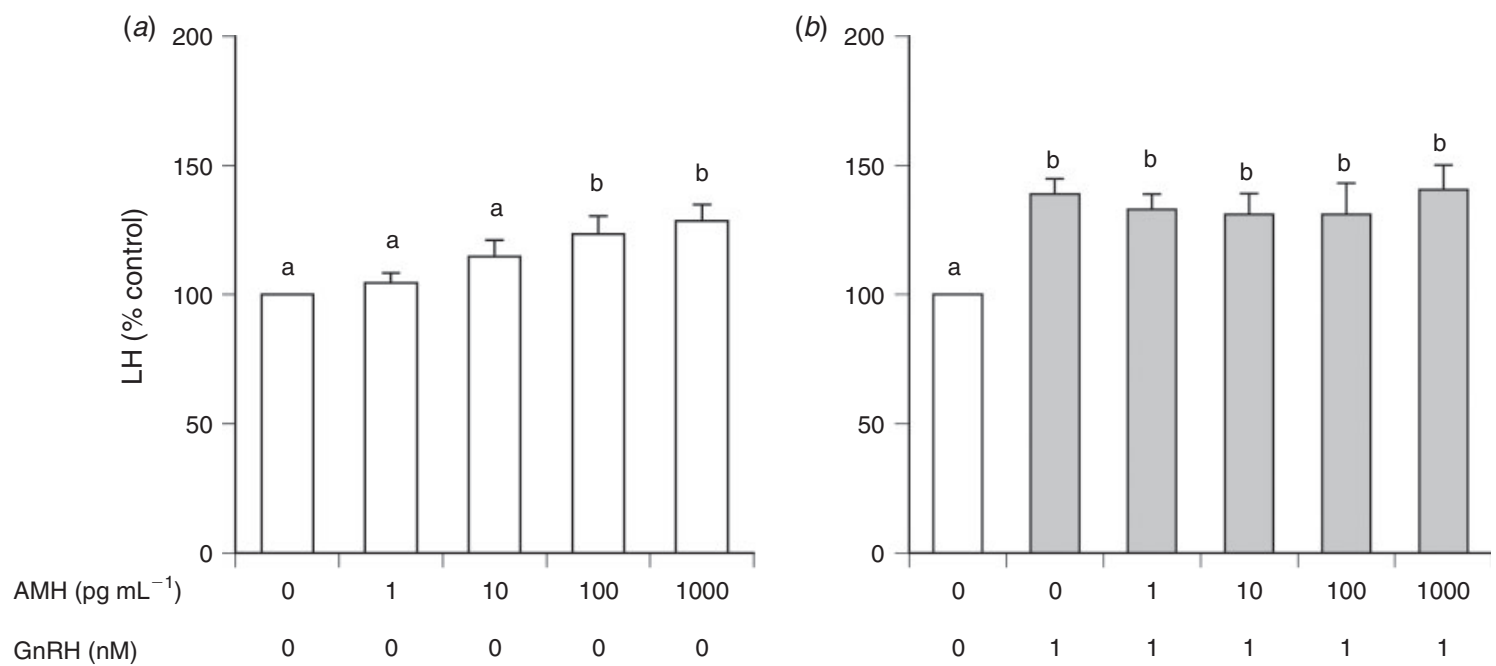

Fig. 7. Comparison of the effects of different concentrations of anti-Müllerian hormone (AMH) in the medium in the (a) absence or (b) presence of $1 \mathrm{nM}$ gonadotrophin-releasing hormone $(\mathrm{GnRH})$ on LH secretion from cultured anterior pituitary (AP) cells of postpubertal heifers. The LH concentrations in control cells (cultured in medium alone without AMH and GnRH) were averaged and set at $100 \%$, and the mean $\mathrm{LH}$ concentration for each treatment group is expressed as a percentage of the control value. Data are expressed as the mean \pm s.e.m. Different letters indicate significant differences $(P<0.05)$.
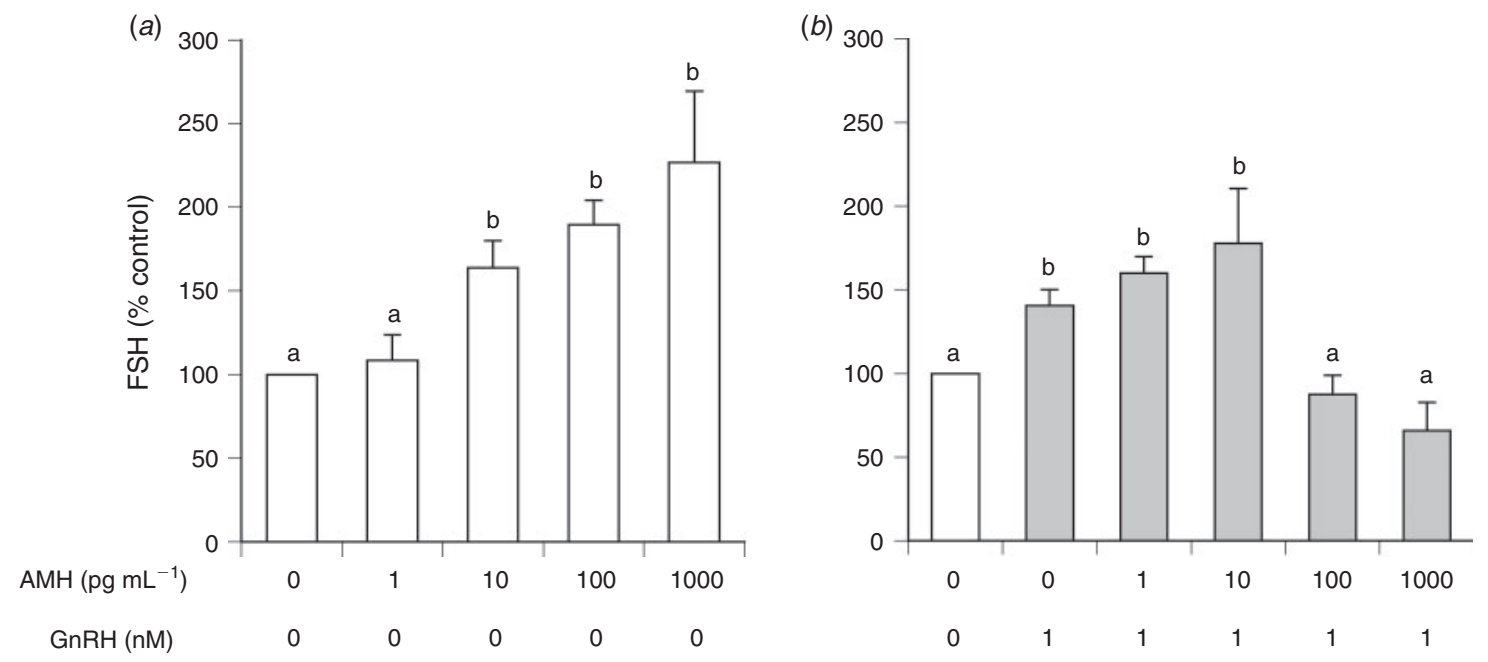

Fig. 8. Comparison of the effects of various concentrations of anti-Müllerian hormone (AMH) in the medium in the $(a)$ absence or (b) presence of $1 \mathrm{nM}$ gonadotrophin-releasing hormone (GnRH) on FSH secretion from cultured anterior pituitary (AP) cells of postpubertal heifers. The FSH concentrations in control cells (cultured in medium alone without AMH and GnRH) were averaged and set at $100 \%$, and the mean FSH concentration for each treatment group is expressed as a percentage of the control value. Data are expressed as the mean \pm s.e.m. Different letters indicate significant differences $(P<0.05)$.

approximately 5 and $2 \mathrm{kDa}$, because AMHR2 is $O$-glycosylated (Faure et al. 1996). The full-length monomers in APs appeared as a doublet, whereas those in the ovary appeared as a single band in the present study. Therefore, the present study suggests that bovine AMHR2 is glycosylated, and the difference in the number of full-length monomers between the AP and ovary may be because of differences in glycosylation.

The anti-AMHR2 antibody revealed similar bands in the two tissues in western blotting analyses. However, the intensity of the bands was weaker for AP than ovarian tissue. Nevertheless, $\beta$-actin bands showed weaker staining in AP tissue than ovarian tissue. This suggests that the AP cell lanes were loaded with a lower amount of proteins than expected. A second difference between AP and ovarian cells was the absence of the dimeric AMHR2 band in AP cells. However, this may be the consequence of the lower protein amount used in the AP cell western blot. In fact, the high molecular weight band was detectable in the ovarian tissue extract only at the highest dose (i.e. $16 \mu \mathrm{g}$ per lane).

We found that approximately $20 \%$ of AMHR2-positive cells were non-gonadotrophs. At the time of manuscript preparation, 
no reports had been published on AMHR2 in non-gonadotrophs. An AMHR2 polymorphism (482 $\mathrm{A}>\mathrm{G}$ ) was associated with lower prolactin levels in women with polycystic ovary syndrome (Georgopoulos et al. 2013). Therefore, lactotrophs may express AMHR2 to play an important role in polycystic ovary syndrome, which is a possibility that bears further consideration in future investigations.

In conclusion, AMHR2 is expressed in the gonadotrophs of postpubertal heifers to control gonadotrophin secretion.

\section{Conflicts of interest}

The authors declare no conflicts of interest.

\section{Acknowledgements}

Both Onalenna Kereilwe and Kiran Pandey were supported by scholarships from the Ministry of Education, Culture, Sports, Science, and Technology (MEXT). This research was supported, in part, by a Grant-in Aid for Scientific Research from Yamaguchi University Foundation (Yamaguchi, Japan) to Hiroya Kadokawa. This research was supported, in part, by a Grant-in Aid for Scientific Research (JSPS Kakenhi Grant Number 15K07693) from Japan Society for the Promotion of Science (Tokyo, Japan) to Hiroya Kadokawa. The authors thank Dr A. F. Parlow of the National Hormone and Peptide Program (Harbor-UCLA Medical Centre Torrance, CA, USA) for supplying the radioimmunoassay kits.

\section{References}

Bédécarrats, G. Y., O’Neill, F. H., Norwitz, E. R., Kaiser, U. B., and Teixeira, J. (2003). Regulation of gonadotropin gene expression by Mullerian inhibiting substance. Proc. Natl Acad. Sci. USA 100, 93489353. doi:10.1073/PNAS.1633592100

Belville, C., Van Vlijmen, H., Ehrenfels, C., Pepinsky, B., Rezaie, A. R., Picard, J. Y., Josso, N., di Clemente, N., and Cate, R. L. (2004). Mutations of the anti-Mullerian hormone gene in patients with persistent Mullerian duct syndrome: biosynthesis, secretion, and processing of the abnormal proteins and analysis using a three-dimensional model. Mol. Endocrinol. 18, 708-721. doi:10.1210/ME.2003-0358

Bhide, P., and Homburg, R. (2016). Anti-Müllerian hormone and polycystic ovary syndrome. Best Pract. Res. Clin. Obstet. Gynaecol. 37, 38-45. doi:10.1016/J.BPOBGYN.2016.03.004

Borromeo, V., Amsterdam, A., Berrini, A., Gaggioli, D., Dantes, A., and Secchi, C. (2004). Characterization of biologically active bovine pituitary FSH purified by immunoaffinity chromatography using a monoclonal antibody. Gen. Comp. Endocrinol. 139, 179-189. doi:10.1016/J.YGCEN. 2004.09.005

Campbell, B. K., Clinton, M., and Webb, R. (2012). The role of antiMullerian hormone (AMH) during follicle development in a monovulatory species (sheep). Endocrinology 153, 4533-4543. doi:10.1210/ EN.2012-1158

Dewailly, D., Andersen, C. Y., Balen, A., Broekmans, F., Dilaver, N., Fanchin, R., Griesinger, G., Kelsey, T. W., La Marca, A., Lambalk, C., Mason, H., Nelson, S. M., Visser, J. A., Wallace, W. H., and Anderson, R. A. (2014). The physiology and clinical utility of anti-Mullerian hormone in women. Hum. Reprod. Update 20, 370-385. doi:10.1093/ HUMUPD/DMT062

Durlinger, A. L., Gruijters, M. J., Kramer, P., Karels, B., Kumar, T. R., Matzuk, M. M., Rose, U. M., de Jong, F. H., Uilenbroek, J. T., Grootegoed, J. A., and Themmen, A. P. (2001). Anti-Mullerian hormone attenuates the effects of FSH on follicle development in the mouse ovary. Endocrinology 142, 4891-4899. doi:10.1210/ENDO.142.11.8486

Faure, E., Gouédard, L., Imbeaud, S., Cate, R., Picard, J. Y., Josso, N., and di Clemente, N. (1996). Mutant isoforms of the anti-Müllerian hormone type II receptor are not expressed at the cell membrane. J. Biol. Chem. 271, 30571-30575. doi:10.1074/JBC.271.48.30571

Garrel, G., Racine, C., L'Hôte, D., Denoyelle, C., Guigon, C. J., di Clemente, N., and Cohen-Tannoudji, J. (2016). Anti-Müllerian hormone: a new actor of sexual dimorphism in pituitary gonadotrope activity before puberty. Sci. Rep. 6, 23790. doi:10.1038/SREP23790

Georgopoulos, N. A., Karagiannidou, E., Koika, V., Roupas, N. D., Armeni, A., Marioli, D., Papadakis, E., Welt, C. K., and Panidis, D. (2013). Increased frequency of the anti-Mullerian-inhibiting hormone receptor 2 (AMHR2) $482 \mathrm{~A}>\mathrm{G}$ polymorphism in women with polycystic ovary syndrome: relationship to luteinizing hormone levels. J. Clin. Endocrinol. Metab. 98, E1866-E1870. doi:10.1210/JC.2013-2458

Hashizume, T., Horiuchi, M., Tate, N., Nonaka, S., Kojima, M., Hosoda, H., and Kangawa, K. (2003). Effects of ghrelin on growth hormone secretion from cultured adenohypophysial cells in cattle. Endocr. J. 50, 289-295. doi:10.1507/ENDOCRJ.50.289

Hashizume, T., Onodera, Y., Shida, R., Isobe, E., Suzuki, S., Sawai, K., Kasuya, E., and Nagy, G. M. (2009). Characteristics of prolactinreleasing response to salsolinol (SAL) and thyrotropin-releasing hormone (TRH) in ruminants. Domest. Anim. Endocrinol. 36, 99-104. doi:10.1016/J.DOMANIEND.2008.11.001

Head, B. P., Patel, H. H., and Insel, P. A. (2014). Interaction of membrane/lipid rafts with the cytoskeleton: impact on signaling and function: membrane/ lipid rafts, mediators of cytoskeletal arrangement and cell signaling. Biochim. Biophys. Acta 1838, 532-545. doi:10.1016/J.BBAMEM.2013.07.018

Hernandez-Medrano, J. H., Campbell, B. K., and Webb, R. (2012). Nutritional influences on folliculogenesis. Reprod. Domest. Anim. 47(Suppl. 4), 274-282. doi:10.1111/J.1439-0531.2012.02086.X

Hirokawa, T., Boon-Chieng, S., and Mitaku, S. (1998). SOSUI: classification and secondary structure prediction system for membrane proteins. Bioinformatics 14, 378-379. doi:10.1093/BIOINFORMATICS/14.4.378

Hirschhorn, T., di Clemente, N., Amsalem, A. R., Pepinsky, R. B., Picard, J. Y., Smorodinsky, N. I., Cate, R. L., and Ehrlich, M. (2015). Constitutive negative regulation in the processing of the anti-Müllerian hormone receptor II. J. Cell Sci. 128, 1352-1364. doi:10.1242/JCS.160143

Hopp, T. P., and Woods, K. R. (1981). Prediction of protein antigenic determinants from amino acid sequences. Proc. Natl Acad. Sci. USA 78, 3824-3828. doi:10.1073/PNAS.78.6.3824

Hossain, M. S., Mineno, K., and Katafuchi, T. (2016). Neuronal orphan G-protein coupled receptor proteins mediate plasmalogens-induced activation of ERK and Akt signaling. PLoS One 11, e0150846. doi:10.1371/JOURNAL.PONE.0150846

Ilha, G. F., Rovani, M. T., Gasperin, B. G., Ferreira, R., de Macedo, M. P., Neto, O. A., Duggavathi, R., Bordignon, V., and Goncalves, P. B. (2016). Regulation of anti-Mullerian hormone and its receptor expression around follicle deviation in cattle. Reprod. Domest. Anim. 51, 188-194. doi:10.1111/RDA.12662

Iqbal, J., Latchoumanin, O., Sari, I. P., Lang, R. J., Coleman, H. A., Parkington, H. C., and Clarke, I. J. (2009). Estradiol-17beta inhibits gonadotropin-releasing hormone-induced $\mathrm{Ca}^{2+}$ in gonadotropes to regulate negative feedback on luteinizing hormone release. Endocrinology 150, 4213-4220. doi:10.1210/EN.2009-0092

Ireland, J. L., Scheetz, D., Jimenez-Krassel, F., Themmen, A. P., Ward, F., Lonergan, P., Smith, G. W., Perez, G. I., Evans, A. C., and Ireland, J. J. (2008). Antral follicle count reliably predicts number of morphologically healthy oocytes and follicles in ovaries of young adult cattle. Biol. Reprod. 79, 1219-1225. doi:10.1095/BIOLREPROD.108.071670

Kadokawa, H., Suzuki, S., and Hashizume, T. (2008). Kisspeptin-10 stimulates the secretion of growth hormone and prolactin directly from cultured bovine anterior pituitary cells. Anim. Reprod. Sci. 105, 404-408. doi:10.1016/J.ANIREPROSCI.2007.11.005

Kadokawa, H., Pandey, K., Nahar, A., Nakamura, U., and Rudolf, F. O. (2014). Gonadotropin-releasing hormone (GnRH) receptors of cattle 
aggregate on the surface of gonadotrophs and are increased by elevated GnRH concentrations. Anim. Reprod. Sci. 150, 84-95. doi:10.1016/ J.ANIREPROSCI.2014.09.008

Koizumi, M., and Kadokawa, H. (2017). Positive correlations of age and parity with plasma anti-Müllerian hormone concentrations in Japanese Black cows. J. Reprod. Dev. 63, 205-209. doi:10.1262/JRD.2016-088

Kushnir, V. A., Seifer, D. B., Barad, D. H., Sen, A., and Gleicher, N. (2017) Potential therapeutic applications of human anti-Müllerian hormone $(\mathrm{AMH})$ analogues in reproductive medicine. J. Assist. Reprod. Genet. 34, 1105-1113. doi:10.1007/S10815-017-0977-4

Manders, E. M. M., Verbeek, F. J., and Aten, J. A. (1993). Measurement of co-localization of objects in dual-colour confocal images. J. Microsc. 169, 375-382. doi:10.1111/J.1365-2818.1993.TB03313.X

Martin, T. L., Fogwell, R. L., and Ireland, J. J. (1991). Concentrations of inhibins and steroids in follicular fluid during development of dominant follicules in heifers. Biol. Reprod. 44, 693-700. doi:10.1095/BIOLRE PROD44.4.693

Matteri, R. L., Roser, J. F., Baldwin, D. M., Lipovetsky, V., and Papkoff, H. (1987). Characterization of a monoclonal antibody which detects luteinizing hormone from diverse mammalian species. Domest. Anim. Endocrinol. 4, 157-165. doi:10.1016/0739-7240(87)90011-7

Miyamoto, Y., Skarzynski, D. J., and Okuda, K. (2000). Is tumor necrosis factor alpha a trigger for the initiation of endometrial prostaglandin $\mathrm{F}$ (2alpha) release at luteolysis in cattle? Biol. Reprod. 62, 1109-1115. doi:10.1095/BIOLREPROD62.5.1109

Monniaux, D., Baril, G., Laine, A. L., Jarrier, P., Poulin, N., Cognié, J., and Fabre, S. (2011). Anti-Mullerian hormone as a predictive endocrine marker for embryo production in the goat. Reproduction 142, 845-854. doi:10.1530/REP-11-0211

Nakamura, U., Rudolf, F. O., Pandey, K., and Kadokawa, H. (2015). The non-steroidal mycoestrogen zeranol suppresses luteinizing hormone secretion from the anterior pituitary of cattle via the estradiol receptor GPR30 in a rapid, non-genomic manner. Anim. Reprod. Sci. 156, 118-127. doi:10.1016/J.ANIREPROSCI.2015.03.009

Navratil, A. M., Song, H., Hernandez, J. B., Cherrington, B. D., Santos, S. J., Low, J. M., Do, M. H., and Lawson, M. A. (2009). Insulin augments gonadotropin-releasing hormone induction of translation in LbetaT2 cells. Mol. Cell. Endocrinol. 311, 47-54. doi:10.1016/J.MCE. 2009.07.014

Nett, T. M., Cermak, D., Braden, T., Manns, J., and Niswender, G. (1987). Pituitary receptors for GnRH and estradiol, and pituitary content of gonadotropins in beef cows. I. Changes during the estrous cycle. Domest. Anim. Endocrinol. 4, 123-132. doi:10.1016/0739-7240(87)90006-3

Nussey, S. S., and Whitehead, S. A. (2001). The pituitary gland In 'Endocrinology: An Integrated Approach'. (Eds S. S. Nussey and S. A. Whitehead.) pp. 283-334. (BIOS Scientific Publishers: Oxford.)

Pals, K., Roudbaraki, M., and Denef, C. (2008). Growth hormone-releasing hormone and glucocorticoids determine the balance between luteinising hormone $(\mathrm{LH})$ beta- and $\mathrm{LH}$ beta/follicle-stimulating hormone betapositive gonadotrophs and somatotrophs in the 14-day-old rat pituitary tissue in aggregate cell culture. J. Neuroendocrinol. 20, 535-548. doi:10.1111/J.1365-2826.2008.01698.X

Pandey, K., Nahar, A., and Kadokawa, H. (2016). Method for isolating pure bovine gonadotrophs from anterior pituitary using magnetic nanoparticles and anti-gonadotropin-releasing hormone receptor antibody. J. Vet. Med. Sci. 78, 1699-1702. doi:10.1292/JVMS.16-0157

Pandey, K., Kereilwe, O., Borromeo, V., and Kadokawa, H. (2017). Heifers express G-protein coupled receptor 61 in anterior pituitary gonadotrophs in stage-dependent manner. Anim. Reprod. Sci. 181, 93-102. doi:10.1016/J.ANIREPROSCI.2017.03.020

Pandey, K., Kereilwe, O., and Kadokawa, H. (2018). Heifers express G-protein coupled receptor 153 in anterior pituitary gonadotrophs in stage-dependent manner. Anim. Sci. J. 89, 60-71.
Pfeiffer, K. E., Jury, L. J., and Larson, J. E. (2014). Determination of antiMüllerian hormone at estrus during a synchronized and a natural bovine estrous cycle. Domest. Anim. Endocrinol. 46, 58-64. doi:10.1016 J.DOMANIEND.2013.05.004

Poole, D. H., Ocón-Grove, O. M., and Johnson, A. L. (2016). Anti-Müllerian hormone (AMH) receptor type II expression and AMH activity in bovine granulosa cells. Theriogenology 86, 1353-1360. doi:10.1016/J.THER IOGENOLOGY.2016.04.078

Ribeiro, E. S., Bisinotto, R. S., Lima, F. S., Greco, L. F., Morrison, A., Kumar, A., Thatcher, W. W., and Santos, J. E. (2014). Plasma antiMüllerian hormone in adult dairy cows and associations with fertility. J. Dairy Sci. 97, 6888-6900. doi:10.3168/JDS.2014-7908

Rico, C., Médigue, C., Fabre, S., Jarrier, P., Bontoux, M., Clément, F., and Monniaux, D. (2011). Regulation of anti-Müllerian hormone production in the cow: a multiscale study at endocrine, ovarian, follicular, and granulosa cell levels. Biol. Reprod. 84, 560-571. doi:10.1095/BIOLRE PROD.110.088187

Ritter, S. L., and Hall, R. A. (2009). Fine-tuning of GPCR activity by receptor-interacting proteins. Nat. Rev. Mol. Cell Biol. 10, 819-830. doi:10.1038/NRM2803

Rocha, R. M., Lima, L. F., Carvalho, A. A., Chaves, R. N., Bernuci, M. P., Rosa-e-Silva, A. C., Rodrigues, A. P., Campello, C. C., and Figueiredo, J. R. (2016). Immunolocalization of the anti-Müllerian hormone (AMH) in caprine follicles and the effects of AMH on in vitro culture of caprine pre-antral follicles enclosed in ovarian tissue. Reprod. Domest. Anim. 51, 212-219. doi:10.1111/RDA.12668

Sakalar, C., Mazumder, S., Johnson, J. M., Altuntas, C. Z., Jaini, R., Aguilar, R., Naga Prasad, S. V., Connolly, D. C., and Tuohy, V. K (2015). Regulation of murine ovarian epithelial carcinoma by vaccination against the cytoplasmic domain of anti-Müllerian hormone receptor II. J. Immunol. Res. 2015, 630287. doi:10.1155/2015/630287

Satake, H., Matsubara, S., Aoyama, M., Kawada, T., and Sakai, T. (2013) GPCR heterodimerization in the reproductive system: functional regulation and implication for biodiversity. Front. Endocrinol. (Lausanne) $\mathbf{4}$, 100. doi:10.3389/FENDO.2013.00100

Seifer, D. B., and Merhi, Z. (2014). Is AMH a regulator of follicular atresia? J. Assist. Reprod. Genet. 31, 1403-1407. doi:10.1007/S10815-0140328-7

Simons, K., and Tooter, D. (2000). Lipid rafts and signal transduction. Nat. Rev. Mol. Cell Biol. 1, 31-39. doi:10.1038/35036052

Suzuki, S., Kadokawa, H., and Hashizume, T. (2008). Direct kisspeptin-10 stimulation on luteinizing hormone secretion from bovine and porcine anterior pituitary cells. Anim. Reprod. Sci. 103, 360-365. doi:10.1016/ J.ANIREPROSCI.2007.05.016

Townsend, J., Sneddon, C. L., and Tortonese, D. J. (2004). Gonadotroph heterogeneity, density and distribution, and gonadotroph-lactotroph associations in the pars distalis of the male equine pituitary gland. J. Neuroendocrinol. 16, 432-440. doi:10.1111/J.1365-2826.2004. 01174.X

Visser, J. A., and Themmen, A. P. (2014). Role of anti-Mullerian hormone and bone morphogenetic proteins in the regulation of FSH sensitivity. Mol. Cell. Endocrinol. 382, 460-465. doi:10.1016/J.MCE.2013.08.012

Wehmeyer, L., Du Toit, A., Lang, D. M., and Hapgood, J. P. (2014). Lipid raft- and protein kinase $\mathrm{C}$-mediated synergism between glucocorticoidand gonadotropin-releasing hormone signaling results in decreased cell proliferation. J. Biol. Chem. 289, 10235-10251. doi:10.1074/JBC. M113.544742

Young, J. M., Juengel, J. L., Dodds, K. G., Laird, M., Dearden, P. K., McNeilly, A. S., McNatty, K. P., and Wilson, T. (2008). The activin receptor-like kinase 6 Booroola mutation enhances suppressive effects of bone morphogenetic protein 2 (BMP2), BMP4, BMP6 and growth and differentiation factor-9 on FSH release from ovine primary pituitary cell cultures. J. Endocrinol. 196, 251-261. doi:10.1677/JOE-07-0148 